\title{
Cost and Returns Analysis of Sugarcane Production in Baghpat district of Western Uttar Pradesh, India
}

\author{
Lalit Kumar Verma* and Arun Solanki \\ Department of Agricultural Economics, J.V. College Baraut, Baghpat, -250611 (U.P.), India \\ *Corresponding author
}

Keywords

Sugarcane, Cost of cultivation, Gross return, Net return, Input output ratio

Article Info

Accepted:

15 December 2019

Available Online:

20 January 2020

A B S T R A C T

The Present Study deals with the cost and return of sugarcane in the Baghpat district of Uttar Pradesh state. The district is purposely selected for this study because these district main commercial activities of the people living in this region are making and selling Gur and Khandsari Sugar, which is an agro-based industry. It was conducted in Baraut and Chhaprauli blocks in the district. The primary data were collected for the year 20162017. Primary data were collected from the sample respondents by conducting personal interview and pretested schedule. 80 farmers were selected randomly from two blocks out of which, marginal (23), small (36), medium (12) and large (09). The overall cost of cultivation of sugarcane was found to be Rs 87491.30 per hectare and cost of production was Rs 105.70 per quintal of sugarcane. The yield of sugarcane was $831.23 \mathrm{q} / \mathrm{ha}$ in sample farms. The input output ratio over total cost was noticed to be $1: 2.56$.

\section{Introduction}

Sugarcane is an important commercial crop of the world and the cultivation of sugarcane, in India dates back to Pre-Vedic period (2000 B.C.). India is one of the principal centers of the origin of the sugarcane. Sugarcane is grown in diversified climatic condition i.e. tropical and sub-tropical. Sugarcane cultivation and development of sugar industry runs parallel to the growth of human civilization and is as old as agriculture. The importance and use of sugarcane and sugar in the country's socio-economic milieu is deep rooted and immense. In the current day rural economy set up sugarcane cultivation and sugar industry has been focal point for socioeconomic development in rural areas by mobilizing rural resources, generating employment and higher income, transport and communication facilities. 
Sugarcane (Saccharum spp.) is an important commercial crop in India and plays a pivotal role in agricultural and industrial economy of our country. Sugarcane is an important commercial crop of the world and more than 100 Countries produce sugar, at present Brazil, Cuba, Mexico, India and Thailand are the leading producers of sugarcane. Currently 69 per cent of the world's sugar is consumed in the country of region. Globally, sugarcane is cultivated over an area of 20.10 million hectares with a production of 1,318.10 million tones and productivity of 65.5 tonnes per hectare. Sugarcane area and productivity differ widely from country to country. Brazil has the highest area (5.34 million hectares) while Australia has the highest productivity (85.1 tonnes per hectare) India ranks second among the sugarcane growing countries of the world in the both area and production after Brazil with an area under sugarcane cultivation of 4.94 million hectares with an average yield is 68.6 tons per hectare. ${ }^{1}$ Among different states of the country, Uttar Pradesh occupies first place in area (22.34 lakhs hectare) and production 1623.38 lakhs million tons (2016-17) but in terms of productivity it ranks seventh. ${ }^{22}$ Baghpat district of Sugarcane area 76387 thousand hectare and production 5718.88 million tons (2016-17). ${ }^{2}$

Sugarcane is an intensive input utilization and varies from region to region and farmer to farmer. Input price is continuously increased. Besides that farmers are facing the problem of input availability at proper time, inadequate quantity and with time taking marketing process of the cane untimely and late payment of the produce by the sugar mills.

Keeping in view the above discussion and importance of the sugarcane cultivation, the present study was an attempt to study the economics of cost and return of sugarcane production in the study area.

\section{Materials and Methods}

The present study pertains to Baghpat district of Western Uttar Pradesh. A list of the entire villages was obtained from the block head quarters of each selected block and two villages from each list was selected randomly, Baoli, Malakpur village from Baraut Block and Kakadipur, Basoli village from Chhaprauli Block of Baghpat district for the study purpose therefore having highest area under sugarcane crops cultivation. From the selected villages, random samples of 20 respondents from each village were selected. Finally, samples of 80 farmers were selected for the present study. Then, selected farmers were divided into four categories i.e. 23 marginal farmer (having land up to one hectare), 36 small farmer (1-2 hectare), 12 medium farmer (2-4 hectare) and 09 Large farmer (4-hetare to above), based upon their operational size of land holding by using standard classification given by Department of Land Resources, Government of India. The primary data were collected for the year 201617. Primary data were collected from the stratified sample respondents by conducting personal interview and pretested schedule. Collected data were tabulated according to need and purpose of study. Simple tabular analysis was made. To workout economics of sugarcane production, different cost concept such as cost ' $\mathrm{A}$ ', cost 'B' and cost ' $\mathrm{C}$ ' were used.

Cost A1 = All actual expenses in cash and kind incurred in production by the producer. The items covered in costs on:

i) Hired human labour, ii) Hired bullock labour, iii) Owned bullock labour, iv) Home produced/purchased seed, v) Plant protection chemicals, vi) Home produced/purchased manure, vii) Fertilizers, viii) Depreciation on farm machinery, equipment and farm building, ix) Irrigation, $\mathrm{x}$ ) Land revenue, land 
development tax and other taxes, xi) Interest on working capital, xii) Interest on crop loan and xiii) Miscellaneous expenses.

Cost $\mathrm{A} 2=$ Cost $\mathrm{A} 1+$ Rent paid for leased-in land

Cost $\mathrm{B} 1=$ Cost $\mathrm{A} 1+$ Interest on value of owned capital assets (excluding land)

Cost $\mathrm{B} 2=$ Cost $\mathrm{B} 1+$ Rental value of owned land (net of land revenue) and rent paid for leased-in land

Cost $\mathrm{C} 1=$ Cost B1 + Imputed value of family labour

Cost $\mathrm{C} 2=$ Cost $\mathrm{B} 2+$ Imputed vale of family labour

Cost $\mathrm{C} 3=\operatorname{Cost} \mathrm{C} 2+10$ per cent Cost $\mathrm{C} 2$

\section{Income over different cost}

Income over cost A1 $=$ Output - Cost $A 1$ Income over cost A2 = Output - Cost A2 Income over cost B1 = Output - Cost B1 Income over cost B2 = Output - Cost B2 Income over cost $\mathrm{C} 1=$ Output $-\mathrm{Cost} \mathrm{C} 1$ Income over cost $\mathrm{C} 2=$ Output - Cost $\mathrm{C} 2$ Income over cost C3 = Output - Cost C3

\section{Results and Discussion}

\section{Cost of cultivation of sugarcane}

Table 1.1 shows cost of cultivation of sugarcane per hectare, it reveals that irrespective to the farm size of holdings, the total cost of cultivation of sugarcane of sample farms was Rs 87491.30 per hectare in which the share of total variable cost was 85.11 per cent followed by total fixed cost which was found to be 14.82 per cent. In total variable cost the shares was found to be maximum in human labour cost 40.20 per cent followed by total material cost 33.01 per cent, cost of total power used was observed to be 7.59 per cent and interest on working capital was 4.31 per cent, respectively. In materials cost, the share of seed was 17.11 per cent and fertilizer 11.36 per cent was noticed to be the major cost. While in human labour cost, the share of hired labour cost being 21.02 per cent was comparatively more than that of family labour cost 19.18 per cent. The share of machine power 5.60 per cent was more than that of bullock power 1.99 per cent. In total fixed cost, the rental value of land in Baghpat district was Rs 12000 per hectare and Rs 25.00 was paid as land revenue. The total fixed cost was comparatively more than the interest on working capital. The total cost of cultivation of sugarcane was increasing with respect to farm size of holdings and was found to be maximum under large farms Rs 92899.07 per hectare and minimum in marginal farm Rs 73661.04 per hectare. It is important to note that total variable cost was increasing with respect to the farm size. Thus, it could be concluded that total cost of cultivation was increasing with respect to farm size holding due to bigger farmers could incurred more expenditure on the material inputs.

\section{Measures of farm profit in sugarcane}

Table 1.2 shows the measures of farm profit in sugarcane has been understand by considering the economic parameters viz; yield of sugarcane, cost of cultivation, gross return, net return, cost of production, and input-output ratio, which is presented in Table 1.2 It has been observed from empirical findings that net return over total cost of cultivation of sugarcane was Rs 136941.07 per hectare, irrespective to the farm size holding and it varying from Rs 109007.50 to Rs 147873.43 per hectare for marginal to large farms size. 
Table.1 Costs of cultivation of sugarcane under different farm size (Rs/ha)

\begin{tabular}{|c|c|c|c|c|c|}
\hline Particular & Marginal & Small & Medium & Large & Overall \\
\hline \multicolumn{6}{|c|}{ a. Material cost } \\
\hline I. Seed & $\begin{array}{c}14520.42 \\
(19.71)\end{array}$ & $\begin{array}{c}14880.30 \\
(18.46)\end{array}$ & $\begin{array}{c}14950.30 \\
(17.09)\end{array}$ & $\begin{array}{c}15125.20 \\
(16.28)\end{array}$ & $\begin{array}{c}14977.57 \\
\text { (17.11) }\end{array}$ \\
\hline II. Fertilizer & $\begin{array}{c}6545.32 \\
(8.81)\end{array}$ & $\begin{array}{c}8270.77 \\
(10.20)\end{array}$ & $\begin{array}{c}9617.50 \\
(10.96)\end{array}$ & $\begin{array}{c}11450.30 \\
(12.33)\end{array}$ & $\begin{array}{r}9943.35 \\
(11.36)\end{array}$ \\
\hline III. Plant protection & $\begin{array}{c}1575.39 \\
(2.12)\end{array}$ & $\begin{array}{c}1752.31 \\
(2.26)\end{array}$ & $\begin{array}{c}2065.72 \\
(2.35)\end{array}$ & $\begin{array}{c}2362.70 \\
(2.54)\end{array}$ & $\begin{array}{c}2103.46 \\
(2.39)\end{array}$ \\
\hline IV. Irrigation charges & $\begin{array}{c}1236.45 \\
(1.66)\end{array}$ & $\begin{array}{c}1552.05 \\
(1.91)\end{array}$ & $\begin{array}{c}1898.85 \\
(2.16)\end{array}$ & $\begin{array}{c}2145.35 \\
(2.30)\end{array}$ & $\begin{array}{c}1890.90 \\
(2.15)\end{array}$ \\
\hline Total material cost & $\begin{array}{c}23877.58 \\
(32.30)\end{array}$ & $\begin{array}{c}26455.43 \\
(32.83)\end{array}$ & $\begin{array}{c}28532.37 \\
(32.56)\end{array}$ & $\begin{array}{c}31083.55 \\
(33.45)\end{array}$ & $\begin{array}{c}\text { 28915.28 } \\
\text { (33.01) }\end{array}$ \\
\hline \multicolumn{6}{|c|}{ b. Human labour cost } \\
\hline I. Family labour & $\begin{array}{c}21750.34 \\
(29.28)\end{array}$ & $\begin{array}{c}22650.80 \\
(27.95)\end{array}$ & $\begin{array}{c}15750.20 \\
(17.94)\end{array}$ & $\begin{array}{c}14250.40 \\
(15.37)\end{array}$ & $\begin{array}{c}16783.23 \\
(19.18)\end{array}$ \\
\hline II. Hired labour & $\begin{array}{c}7500.21 \\
(10.10)\end{array}$ & $\begin{array}{c}9750.11 \\
(12.03)\end{array}$ & $\begin{array}{c}19800.30 \\
(22.56)\end{array}$ & $\begin{array}{c}22950.10 \\
(24.67)\end{array}$ & $\begin{array}{c}18392.92 \\
(21.02)\end{array}$ \\
\hline Total human labour cost & $\begin{array}{c}29250.55 \\
(39.38)\end{array}$ & $\begin{array}{c}32400.91 \\
(39.98)\end{array}$ & $\begin{array}{c}35550.50 \\
(40.50)\end{array}$ & $\begin{array}{c}37200.50 \\
(40.04)\end{array}$ & $\begin{array}{c}35176.15 \\
(40.20)\end{array}$ \\
\hline \multicolumn{6}{|c|}{ c. Power use cost } \\
\hline I. Bullock labour & $\begin{array}{c}1176.85 \\
(1.59)\end{array}$ & $\begin{array}{c}1494.89 \\
(1.85)\end{array}$ & $\begin{array}{c}1698.15 \\
(1.95)\end{array}$ & $\begin{array}{c}1984.35 \\
(2.13)\end{array}$ & $\begin{array}{c}1746.09 \\
(1.99)\end{array}$ \\
\hline II. Machine power & $\begin{array}{c}4165.58 \\
(5.60)\end{array}$ & $\begin{array}{c}4486.75 \\
(5.57)\end{array}$ & $\begin{array}{c}4897.10 \\
(5.60)\end{array}$ & $\begin{array}{c}5213.70 \\
(5.61)\end{array}$ & $\begin{array}{c}4904.29 \\
(5.60)\end{array}$ \\
\hline Total power use cost & $\begin{array}{c}5342.43 \\
(7.19)\end{array}$ & $\begin{array}{c}5981.64 \\
(7.42)\end{array}$ & $\begin{array}{c}6595.25 \\
(7.55)\end{array}$ & $\begin{array}{c}7198.05 \\
(7.78)\end{array}$ & $\begin{array}{c}6650.38 \\
(7.59)\end{array}$ \\
\hline d. Interest on working capital & $\begin{array}{c}2570.33 \\
(3.48)\end{array}$ & $\begin{array}{c}2953.10 \\
(3.70)\end{array}$ & $\begin{array}{c}3844.95 \\
(4.60)\end{array}$ & $\begin{array}{c}4286.21 \\
(4.59)\end{array}$ & $\begin{array}{c}3777.06 \\
(4.31)\end{array}$ \\
\hline Total variable cost (A) & 61040.89 & 67791.08 & 74523.07 & 79768.31 & 74518.87 \\
\hline & $(82.86)$ & $(84.14)$ & (85.22) & (85.86) & (85.11) \\
\hline \multicolumn{6}{|c|}{ D. Fixed cost } \\
\hline I. Land revenue & $\begin{array}{l}25.00 \\
(0.03)\end{array}$ & $\begin{array}{l}25.00 \\
(0.03)\end{array}$ & $\begin{array}{l}25.00 \\
(0.02)\end{array}$ & $\begin{array}{l}25.00 \\
(0.02)\end{array}$ & $\begin{array}{l}25.00 \\
(0.03)\end{array}$ \\
\hline II. Rental value of land & $\begin{array}{c}12000.00 \\
(16.29)\end{array}$ & $\begin{array}{c}12000.00 \\
(14.89)\end{array}$ & $\begin{array}{c}12000.00 \\
(13.72)\end{array}$ & $\begin{array}{c}12000.00 \\
(12.91)\end{array}$ & $\begin{array}{c}12000.00 \\
(13.78)\end{array}$ \\
\hline III. Interest on fixed capital & $\begin{array}{l}595.15 \\
(0.80)\end{array}$ & $\begin{array}{l}765.50 \\
(0.94)\end{array}$ & $\begin{array}{l}915.25 \\
(1.04)\end{array}$ & $\begin{array}{c}1105.76 \\
(1.21)\end{array}$ & $\begin{array}{c}947.43 \\
(1.08)\end{array}$ \\
\hline Total fixed cost (B) & $\begin{array}{c}12620.15 \\
(17.13)\end{array}$ & $\begin{array}{c}12790.50 \\
(15.86)\end{array}$ & $\begin{array}{c}12940.25 \\
(14.78)\end{array}$ & $\begin{array}{c}13130.76 \\
(14.14)\end{array}$ & $\begin{array}{c}12972.43 \\
(14.89)\end{array}$ \\
\hline Total $\operatorname{cost}(A+B)$ & 73661.04 & 80581.58 & 87463.32 & 92899.07 & 87491.30 \\
\hline
\end{tabular}

Note -Interest on working capital is computed at $7 \%$ interest rate per annum for the crop period. Figure in parentheses indicate percentage of total cost of cultivation 
Table.2 Measures of farm profit in sugarcane

\begin{tabular}{|c|c|c|c|c|c|c|}
\hline \multirow[t]{2}{*}{ S. No } & \multirow[t]{2}{*}{ Particulars } & \multicolumn{5}{|c|}{ Farm Size } \\
\hline & & Marginal & Small & Medium & Large & Overall \\
\hline 1 & Yield (q/ha) & 676.55 & 754.95 & 830.25 & 891.75 & 831.23 \\
\hline 2 & Cost of cultivation (Rs/ha) & 73661.04 & 80581.58 & 87463.32 & 92899.07 & 87491.30 \\
\hline 3 & Gross return (Rs/ha) & 182668.50 & 203836.50 & 224167.50 & 240772.50 & 224432.37 \\
\hline 4 & Net return (Rs/ha) & 109007.50 & 123254.92 & 136704.18 & 147873.43 & 136941.07 \\
\hline 5 & Cost of production (Rs/q) & 108.87 & 106.73 & 105.34 & 104.17 & 105.38 \\
\hline 6 & Input -Output ratio & 1:2.47 & $1: 2.52$ & $1: 2.56$ & 1:2.59 & $1: 2.56$ \\
\hline
\end{tabular}

Note: - Procurement price of sugarcane was Rs. 325/qt. provided by Govt. of U.P.

Table.3 Break-up of total cost, and income obtained over different cost of sugarcane cultivation

\begin{tabular}{|c|c|c|c|c|c|c|}
\hline \multirow[t]{2}{*}{ S. No } & \multirow[t]{2}{*}{ Particulars } & \multicolumn{4}{|c|}{ Farm size } & \multirow[t]{2}{*}{ Overall } \\
\hline & & Marginal & Small & Medium & Large & \\
\hline \multirow[t]{8}{*}{ A. } & Break-up of cost & & & & & \\
\hline & Cost A1 & 39315.54 & 45165.28 & 58797.87 & 65542.91 & 57760.67 \\
\hline & Cost A2 & 39315.54 & 45165.28 & 58797.87 & 65542.91 & 57760.67 \\
\hline & Cost B1 & 39910.69 & 45930.78 & 59713.12 & 66648.67 & 58708.10 \\
\hline & Cost B2 & 51910.69 & 57930.78 & 71713.12 & 78648.67 & 70708.10 \\
\hline & Cost $\mathrm{C} 1$ & 61661.03 & 68581.58 & 75463.32 & 80899.07 & 75491.30 \\
\hline & Cost $\mathrm{C} 2$ & 73661.03 & 80581.58 & 87463.32 & 92899.07 & 87491.30 \\
\hline & Cost C3 & 81027.14 & 88639.73 & 96209.65 & 102188.97 & 96240.43 \\
\hline \multirow[t]{8}{*}{ B. } & Income over different cost & & & & & \\
\hline & Cost A1 & 143352.96 & 158671.22 & 165369.62 & 175229.58 & 166671.70 \\
\hline & Cost A2 & 143352.96 & 158671.22 & 165369.62 & 175229.58 & 166671.70 \\
\hline & Cost B1 & 142757.80 & 157905.72 & 164454.40 & 174123.83 & 165724.27 \\
\hline & Cost B2 & 130757.80 & 145905.72 & 152454.38 & 162123.83 & 153724.27 \\
\hline & Cost C1 & 121007.46 & 135254.92 & 148704.18 & 159873.43 & 148941.06 \\
\hline & Cost C2 & 109007.46 & 123254.92 & 136704.18 & 147873.43 & 136941.06 \\
\hline & Cost C3 & 101641.35 & 115196.76 & 127957.85 & 138583.52 & 128191.93 \\
\hline
\end{tabular}

The per quintal cost of production was found to be Rs 108.87, Rs 106.73, Rs 105.34 and Rs 104.17 for marginal, small, medium, and large farms size, respectively, while inputoutput ratio were showing increasing trend with respect to farm size. Overall, inputoutput ratio was found to be $1: 2.56$ respectively.
Cost and returns on the basis of different cost concept

Table 1.3 shows generally, 7 cost concepts used for estimation of costs and return by Commission of Agricultural Price and Cost, Government of India. Cost of cultivation of sugarcane of sample farms in the study area has been worked out and presented in Table 
1.3. It is envisaged that Cost A1 is designated as the variable cost including land revenue and interest on working capital and excluding family labour was found to be Rs 57760.67 per hectare on overall basis, which was added with rent paid for lease in land and dignified with Cost A2 which was found to be Rs 57760.67 per hectare which is same as cost A1 because we have not taken land in lease. Cost B1 is cost A1 added with interest on value of owned capital assets (excluding land) which was found to be Rs 58708.10 per hectare. Cost B2 is cost B1 added with rental value of owned land which was found to be Rs 70708.10 per hectare. Cost C1 is cost B1 added with imputed value of family labour which was Rs 75491.30 per hectare. Cost C2 is cost B2 added with imputed value of family labour which is Rs 87491.30 per hectare. Cost $\mathrm{C} 3$ is cost C2 included with value of management input at $10 \%$ of cost $\mathrm{C} 2$ which is Rs 96240.43 per hectare.

Under return obtained over different costs, the return over cost $\mathrm{A} 1, \mathrm{~A} 2, \mathrm{~B} 1, \mathrm{~B} 2, \mathrm{C} 1, \mathrm{C} 2$ and C3 is obtained by subtracting them from Gross return of sugarcane respectively. So, the return over cost A1, A2, B1, B2, C1, C2 and C3 is Rs 166671.70, 166671.70, 165724.27, 153724.27, 148941.06, 136941.06, and 128191.93 per hectare was found respectively.

In conclusion, the major findings are found as on basis of overall, the cost of cultivation of sugarcane was amounted as $87491.30 \mathrm{Rs} / \mathrm{ha}$. major share of cost of cultivation gone to human labour cost being 40.20 percent. The net return against the cost of cultivation observed Rs 136941.07 ha. The input-output ratio of sugarcane came to 1:2.56. The study suggested that during peak period of agricultural operation the unavailability of sufficient labours and available at very high cost. To avoid the escalation of cost and better use of inputs mechanization may be encouraged.

\section{References}

3rd Advance estimates for sugar season (2016-17). March 2017; Vol. 49, No.7 Issued by Department of Agriculture \& farmers Welfare.

Department of Economics \& Statistics, Baghpat (Govt. of U.P.) 2016-17.

Gangwar, L. S. (2002). Economic analysis and resource utilization pattern under irrigated and rainfed conditions in central U. P. Agric. Econ. Res. Review. Conf. Issue. pp. 1-7

Gomatee Singh. (2013). an empirical study of economics of sugarcane cultivation and processing based farming in Uttar Pradesh. Sky Journal of Agricultural Research. 2(1):7-19.

Jadhav, A.D. (2009). Cost and revenue of sugarcane production in India: a price risk analysis. Co-operative Sugar, 40(10):31-36

Kant, Krishna, Tripathi, Siddharth Prakash and Meena, Mamta (2015). Cost of cultivation of sugarcane crop in Meerut district of Uttar Pradesh. Internat. J. Forestry \& Crop Improv., 6 (1) : 41-48.

Kishor Raj, Shukla DS, Singh TR, Yadav SR. (1997). An Enquiry into Economics of Sugar Cultivation in District Sitapur (U.P.). Cooperative Sugar. 29(32):17982.

Kumar Teshu, et al., (2016) Determination of Resource Productivity and Resource Use Efficiency in Sugarcane (Planted and Ratoon) Production in Meerut District of Uttar Pradesh. International Journal of Agriculture Sciences, ISSN: 0975-3710 \& E-ISSN: 0975-9107, Volume 8, Issue 6, pp.-1027-1030.

Kumar, Singh, Jawla and Sachan (2014). Cost and Returns of Sugarcane Production at Different Size Groups of Farms in District Meerut (U. P.), Annals of AgriBio Research 19 (3): 561-565.

Kumbhar, S.B., Shendage, P.N., Jadhav, K.L. and Deokate, T.B. (2009). An economic 
analysis of sugarcane cultivation under different methods of strip plantation in western Maharashtra. Co-operative Sugar, 41(2):35-38.

Maheshwarappa BO, Kunnal LB, Patil SM. (1998). Economics of Production and Marketing of Sugarcane in Karnataka. The Bihar Journal of Agricultural Mktg. 06(3):72-79.

Raj Kishor and Chaurasia, S. P. R. (2001). A study of economic analysis of sugarcane production incentral plains agro-climatic zone of U. P. Cooperative Sugar 32: 715, 717-733

Saini, Sat Pal, Sidhu, Amandeep Singh and Singh, Pritpal (2012). Crop yield, efficiency and economics of autumn and spring sown single bud sugarcane intercropped with pulse crops. Internat. J. Forestry \& Crop Improv., 3 (2) : 6065.

Sen, Madhurima and Kumbhare, S.L. (2009). Sugarcane systems in Uttar Pradesh, Karnataka and Haryana. Commodity Vision, 3(1) : 96-107.

Shinde, Namadeva, Patil, B.L., Murthy, C. and Desai, N.R.M. (2009). Profitability analysis of sugarcane based inters cropping systems in Belgaum district of Karnataka. Karnataka J. Agric. Sci., 22(4): 820-823.

Singh AK, Baghel SS. (1993). Predictive models for the Area, Yield and Production of Sugarcane in Chhattisgarh and its constituent district along with the influence of Area and Yield on the Production- A different approach. Farm Science Journal. 6-9.

Singh, Archana and Srivastava, R. S. L. (2003). Growth and instability in sugarcane production in Uttar Pradesh : a regional study. Indian J. Agric. Econ. $58: 279-282$

Singh, K.V., Kumar, S. and Singh, R.P. (1994). An economics analysis of sugarcane cultivation western Uttar Pradesh. Co-operative Sugar, 25(9/10):381-385.

Sitole, R.S., Agrawal, G.P. and Nahatkar, S.B. (2005). Profitability and resource use efficiency in cultivation of sugarcane in Nimar zone of Madhya Pradesh. Indian Sugar, 55(2): 95-100.

Takale, D.P. and Bhosale, H.A. (2012) Cost, returns and profitability of sugarcane cultivation in Maharashtra: a case study, Cooperative Sugar, Vol.43 No.6 pp.2328

Thennarasu R, Banumathy V. (2011). Economics of Sugarcane Production Using Eco-friendly Technologies in Cuddalore District, Tamil Nadu, Indian J. Agric Econ. 66(1):88-96.

Uttar Pradesh At A Glance 2017

Verma, A.R. (2005). Economic analysis of production and resource use efficiency of potato in Indore district of Madhya Pradesh. Indian Journal of Agricultural Economics, vol. 60. No. 3, July-Sept. P. 515.

\section{How to cite this article:}

Lalit Kumar Verma and Arun Solanki. 2020. Cost and Returns Analysis of Sugarcane Production in Baghpat district of Western Uttar Pradesh, India. Int.J.Curr.Microbiol.App.Sci. 9(01): 733-739. doi: https://doi.org/10.20546/ijcmas.2020.901.080 